\title{
Direct field observations of massive bedload and debris-flow depositions in open check dams
}

\author{
Guillaume Piton ${ }^{1, *}$, Firmin Fontaine ${ }^{1}$, Hervé Bellot ${ }^{1}$, Frédéric Liébault ${ }^{1}$, Coraline Bel $^{1}$, \\ Alain Recking ${ }^{1}$, Thérèse Hugerot ${ }^{2}$ \\ ${ }^{1}$ Université Grenoble Alpes, Irstea, UR ETGR, 2 Rue de la Papeterie, BP76, 38402 Saint Martin \\ d'Hères, France \\ ${ }^{2}$ EDYTEM,UMR 5204 du CNRS, Université de Savoie F-73376 Le Bourget Du Lac, France
}

\begin{abstract}
Sediment detention basins, also called SABO dams, are key facilities in flood protection systems of mountain catchments, specifically in torrents prone to massive bedload transport or debris flows. A better understanding of the processes generating sediment trapping is required to optimize their functioning. Two monitoring stations have been implemented in the French Alps on two torrents: the Manival (SaintNazaire-Les-Eymes) and the Claret (Saint-Julien-Mont-Denis). Time-lapse photos show an event depositing $10,000 \mathrm{~m}^{3}$ of debris flow in a basin in less than six minutes and several events partially filling the other basin with gravel, impairing its capacity to store debris flows later. After a presentation of the catchments, this paper qualitatively analyzes the dynamics of the depositions. It highlights and stresses the consistency and differences between bedload and debris-flow deposition. Overall, despite clear differences of geomorphic activity, deposits tend to fill the trap basins just enough to enable the sediment transport continuity reestablishment through the basin. The open check dams thus play a role only provided that this continuity precondition is completed. These observations enhance our comprehension of massive sediment trapping in torrents and our capacity to better adjust trap maintenance and design to the objective sought in each site.
\end{abstract}

\section{Introduction}

Hundreds of sediment trapping basins with open check dams, also called SABO dams, are used in protection systems of mountain catchments [1]. They are dedicated to the trapping of massive bedload transport or debris flows, to be later mechanically dredged. They complement closed retention check dams, i.e., long term trapping structures that are not mechanically dredged and thus lose their capacity gradually, and sometimes rapidly [1,2]. Both open and closed structures usually strongly disrupt the sediment transport continuity depending of their design and maintenance features. This disruption is regularly excessive, sometimes due to an ill-design. It generally induces shorter life duration for closed

\footnotetext{
* Corresponding author: guillaume.piton@irstea.fr
} 
structures or higher dredging costs for open ones, as well as strong geomorphic downstream effects, e.g., incision and banks' and bridges' undermining [3]. At the same time, these structures provide interesting data on sediment production and torrential processes [4]. Open structures are obviously more promising regarding self-cleaning and partial continuity of the sediment transport. A better understanding of the processes generating sediment trapping is required to better understand torrential processes as well as to optimize these protection structures' functioning on both the risk, economic and environmental aspects.

For such a purpose, the sediment traps of two active torrents of the French Alps - the Manival (Saint-Nazaire-Les-Eymes, bedload and debris flows) and the Claret (Saint-JulienMont-Denis, debris flows) were equipped with Reconyx PC 900 cameras, triggered by geophones. The monitoring station facilities are presented in $[5,6]$. The present paper briefly presents the catchments and novel images of massive bedload and debris-flow depositions in sediment traps. It then provides a qualitative temporal analysis of deposition dynamics. It finally discusses (i) the similarities between depositions of both transport processes and (ii) the geomorphic processes of alluvial- and debris-cones' formation.

\section{Massive bedload retention: the Manival torrent}

\subsection{The Manival's catchment and sediment trap}

The Manival is an active torrent of the Northern French Prealps located in the Chartreuse Massif about 10-km north of Grenoble [7]. The Manival has a rockslope system typical of upland prealpine catchments with formation of thick colluvial deposits below rockwalls and hillsides originating from highly fractured bedrock (Jurassic marly limestones). Because of its steep slopes (mean channel slope: $0.16 \mathrm{~m} . \mathrm{m}^{-1}$; Melton Index: 0.62 ) and its high sediment potential, it is highly prone to bedload transport, debris floods and debris flows with on average one major event every three years. Its catchment with a drainage area of $3.6 \mathrm{~km}^{2}$ is characterized by a remarkable debris fan of $2-\mathrm{km}$ radius. To mitigate the torrential risk, torrent control works have been implemented since the 1890s by the ONF-RTM services, the French torrent-control work institution. Today, the torrent is equipped with (1) more than 180 check dams, (2) artificial levees that confined the flows along a 10-20 m wide single channel, and (3) a sediment detention basin closed by an open check dam.

The sediment detention basin is located $45.271^{\circ} \mathrm{N}, 5.832^{\circ} \mathrm{E}$. Its $100 \mathrm{~m}$-long basin has a specific organization with an upper, 40 m-long platform flat and wide, followed by a deeper and steeper, $60 \mathrm{~m}$-long channel (Fig. 1). The basin is closed by a reinforced concrete open check dam with 5 vertical slots and a trapezoidal spillway. It has a capacity of $25,000 \mathrm{~m}^{3}$.

\subsection{Bedload deposition from Sept. 2015 to Jan. 2017}

No debris flow reached the trap since we started its camera monitoring in 2015. However, it was partially filled by several debris floods, carrying variable amount of bedload (Table 1). The main steps of the progressive trap filling and the influences on the sediment transfer of the basin particular shape, one the one hand, and of the open check dam, on the other hand, are illustrated in Figure 1. In essence, the trap filling occurred in two phases.

The first phase is mostly influenced by the basin shape (Fig. 1a-d). It consisted in the reestablishment of the sediment continuity throughout the upper platform. Massive deposition of gravel under the form of an alluvial fan occurred on the platform at a slope of $0.154 \mathrm{~m} / \mathrm{m}$. Flows showed cycles of multi-thread channels aggrading the region of the fan apex and channelized flow incising the apex and transferring sediment at the fan toe. 

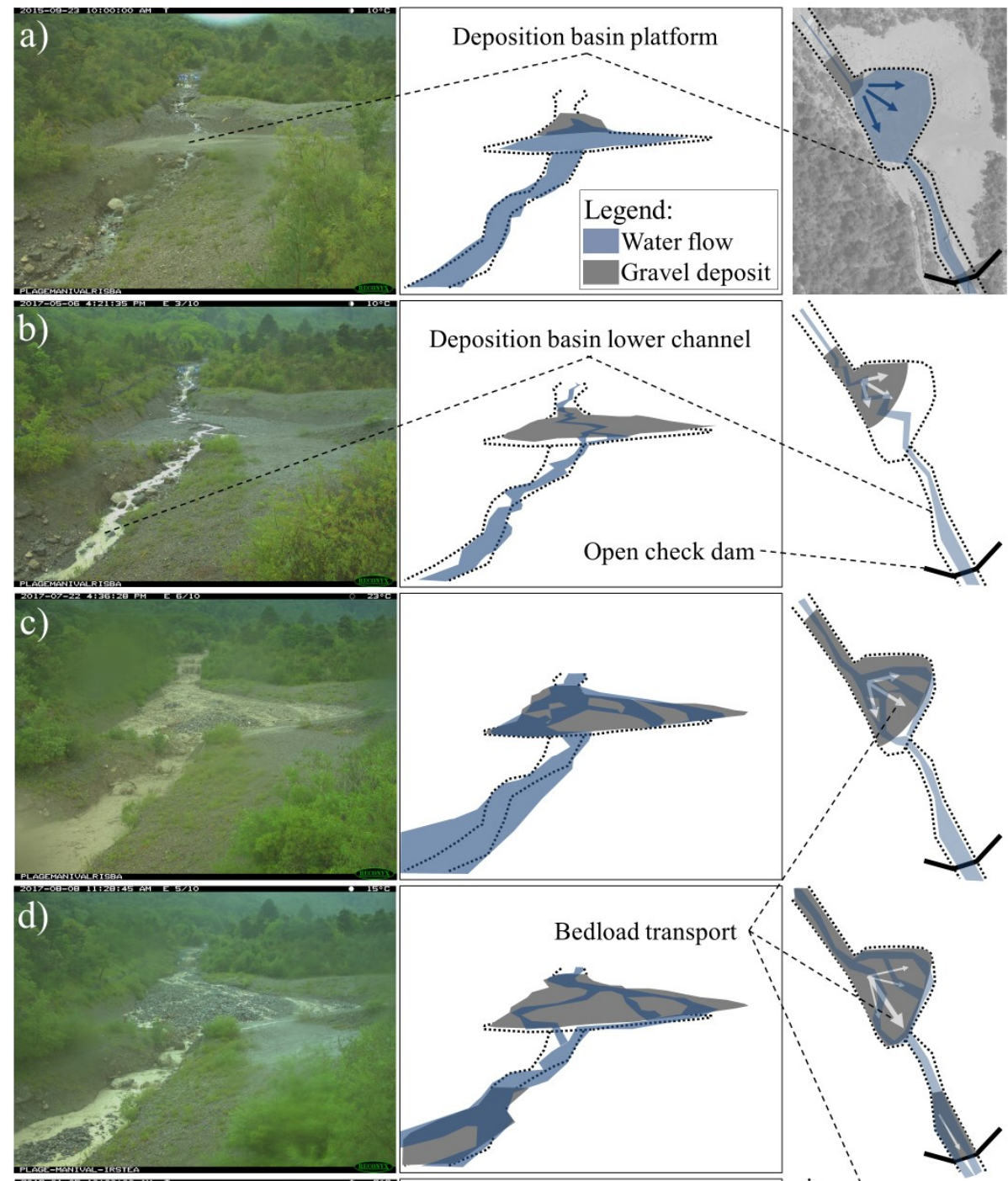

e)
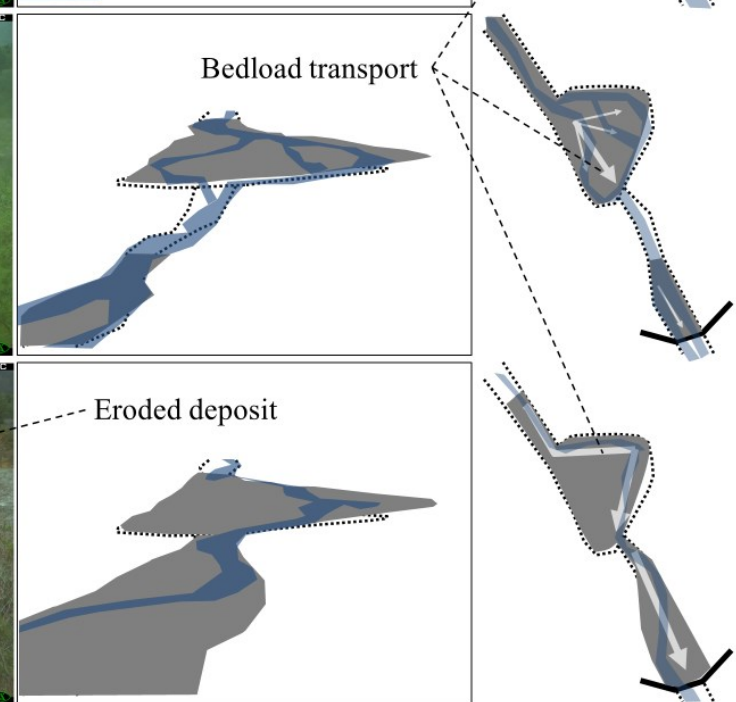

Fig. 1. Camera image and sketches (camera and aerial views) of the Manival sediment trap filling: (a) Picture dating from Sept. $23^{\text {th }}$, 2015, recently-dredged basin, flat platform on which water spread widely. (b) May $5^{\text {th }}, 2017$, only a small sediment volume reached the basin on June, $16^{\text {th }} 2016$, it formed a small fan on part of the upper platform. (c) Jul. $22^{\text {th }} 2017$, debris flood reaching the trap the day before, the fan aggraded and prograded until the platform edge, (d) Aug. $8^{\text {th }}$, 2017, sediment continuity re-establishment while back-filling in the upper channel continued during a second debris flood on Jul. 22 $2^{\text {th }} 2017$; (e) Jan. $5^{\text {th }} 2018$, two floods (Dec. 10 $0^{\text {th }}, 2017$ \& Jan. $4^{\text {th }}, 2018$ ) strongly incised the fan apex and transferred sediment in the lower channel through a stable channel. 
Table 1. Main floods filling the Manival trap between pictures of Figure 1

\begin{tabular}{ccccc}
\hline Date & $\begin{array}{c}\text { Rainfall } \\
{[\mathbf{m m}]}\end{array}$ & $\begin{array}{c}\text { Max intensity on } \\
\mathbf{5} \text { min. [ } \mathbf{m m} / \mathbf{h}]\end{array}$ & Flow pattern & $\begin{array}{c}\text { Sediment continuity } \\
\text { platform } \rightarrow \text { channel }\end{array}$ \\
\hline $6 / 16 / 2016$ & 48.8 & 30.5 & Cycles of & No \\
$07 / 21 / 2017$ & 67.8 & 94.5 & mono- and multi- & No, partial at the end \\
$07 / 22 / 2017$ & 22 & 131 & threads patterns & Partial, yes at the end \\
\hline $12 / 1 / 2017$ & 95.8 & 18.3 & One channel & Yes \\
$01 / 04 / 2018$ & 86.4 & 12.2 & incising the fan & Yes \\
\hline
\end{tabular}

The second phase started once the fan border reached platform side (Fig. 1d-e). The sediment transport continuity was then re-established into the lower channel. The most active fan channel at the time of the reconnection then remained stable. It only slowly shifted on the deposit through bank erosion. No major avulsion with new active channel activation occurred during the second phase, on the contrary to the previous very unstable flow pattern.

Gravels should have theoretically been transferred out of the trap thank to the steeper slope of the lower channel and the $\sim 50 \mathrm{~cm}$-wide slots of open check dam. However a few cubic meters of medium wood pieces clogged the five slots progressively. The open check dam was then nearly no longer open and most of the gravel exported from the platform had finally been trapped in the lower channel (Fig. 1e).

\section{Debris flow retention: The Claret torrent}

\subsection{The Claret's catchment and sediment trap}

The Claret torrent is a right-bank tributary of the Arc river [8]. Its watershed is included in the middle junction of the intra-alpine valley of the Arc (Northern French Alps). The geological constitution of the catchment, formed in the sub-Briançonnais, highlights two sedimentary supplies: black schists, gypsum and cargneules present on the right bank and Jurassic limestones constituting the cliffs of the upper part on the Claret's left bank. The $2.63-\mathrm{km}^{2}$ catchment experiences active erosion on $41 \%$ of its surface. The topographic features (mean channel slope: $0.53 \mathrm{~m} \cdot \mathrm{m}^{-1}$, Melton Index 1.01), the sinuosity of the bed and the relicts of intensive past depositions - e.g., levees and lobes visible on the left bank of the torrential cone - characterize the debris-flow regime of the torrent. Historical archives of floods show that they occur during intense summer storms, with an average frequency of three significant debris-flow events per decade.

Torrent control works began in 1895 . Yet, there is currently no trace of the 260 check dams and 760 meters of landslide drains built between 1897 and 1902. Only post-1950s major check dams and the sediment retention basin built in 1991 with a storage capacity estimated between 15,000 and $18,000 \mathrm{~m}^{3}$ still provide a protective function of the fan [8].

The sediment detention basin is located $45.250^{\circ} \mathrm{N}, 6.418^{\circ} \mathrm{E}$. Its $120 \mathrm{~m}$-long basin is closed by a $9.2 \mathrm{~m}$-high reinforced concrete open check dam. Two slots pierce the dam: a $5.0 \times 1.0 \mathrm{~m}$ slot at the toe of the dam enables low flows to pass. An upper $3.0 \times 1.5 \mathrm{~m}$ slot is activated when the dam is filled of $4.0 \mathrm{~m}$ of sediment or debris flows. A $2 \mathrm{~m}$-high trapezoidal spillway with a basis of $5.0-\mathrm{m}$ guides extreme flows over the dam when the deposit is more than 7-m high. Six debris-flow breakers are located at the basin inlet. They are triangular reinforced concrete blocks organized in a triangular pattern. 


\subsection{The June, 14th 2017 debris flow}

On June 14th, 2017, both the Claret torrent and its East neighbor the Rieu Sec experienced debris flows in the afternoon. A rain gauge recorded a cumulated $14 \mathrm{~mm}$ in 15 minutes at the sediment detention basin. However the intensity and total rainfall could have been higher in the triggering zones due to higher altitude. The storm cell was quite located: (i) another rain gauge, located 3.5-km North in the valley, only measured $6 \mathrm{~mm}$ of cumulated rain, and (ii) the torrents located to the West did not experienced noticeable activity.

The Claret debris flow originated from the Combe Mouillée branch. It passed through 11 check dams only letting lateral levee and deposited about $10,000 \mathrm{~m} 3$ of debris in the sediment detention basin. The remaining volume continued its way downstream letting only few traces and nearly no deposits [9].

\subsection{Open check dam filling dynamics}

The three most downstream debris flow breakers were buried in sediment before the debris flows occurred (Fig. 2a). This likely arises because the basin slope was steeper than usual since the last dredging or other small debris flow depositions.

The debris flow reached its maximum deposition in less than 6 minutes and then progressively partially self-cleaned through the intermediate slot. The main steps and several details are given in Table 2 and Figure 2. The structure filling also occurred in two phases: (i) debris flow spreading on nearly all the basin width at a probably homogeneous depth of deposition and a slope of about 15\% (Fig. 2a-d); (ii) backwater effect once the debris flow reached the dam (Fig. 2 e-f). This second phase consisted in the filling of the area upstream of the open check dam up to $1.1 \mathrm{~m}$ above the upper slot level, i.e., on a depth of $5.1 \mathrm{~m}$. The self-cleaning occurred only for material above the upper slot level and let a deposit with a $6 \%$ slope. The final deposit right to the open check dam was thus 4-m thick.

Table 2. Main steps and their duration in the debris flow (DF) trapping observed in Figure 2

\begin{tabular}{|c|c|c|c|}
\hline Time & Duration & Observation & \\
\hline $03: 20: 54$ & 00:00:00 & DF front reached the basin inlet, spreading of the boulder front started & \\
\hline $03: 21: 14$ & 00:00:20 & First boulder stopped behind the central DF breaker & $\mathrm{a}$ \\
\hline $03: 21: 19$ & 00:00:25 & $\begin{array}{l}\text { The DF boulder front fully deposited, the DF body started depositing in } \\
\text { the basin center behind the DF front deposit. }\end{array}$ & $\mathrm{b}$ \\
\hline $03: 22: 03$ & 00:01:09 & $\begin{array}{l}\text { The flow likely reached the check dam, clogging the bottom slot with } \\
\text { boulders, the DF body deposit reached its maximal extend. }\end{array}$ & \\
\hline $03: 22: 10$ & 00:01:16 & $\begin{array}{c}\text { The check dam backwater effect is visible, a recirculating flow } \\
\text { progressively back filled the basin }\end{array}$ & $\mathrm{d}$ \\
\hline $03: 23: 11$ & $00: 02: 17$ & $\begin{array}{c}\text { Recirculation slowed down, the upper slot was probably activated; most } \\
\text { of the flow progressively went by the slot. }\end{array}$ & e \\
\hline 03:26:51 & 00:05:57 & Maximum level of DF in the basin. Self-cleaning started. & $\mathrm{f}$ \\
\hline 03:31:04 & 00:10:10 & Self-cleaning still in progress, camera stopping (insufficient activity) & \\
\hline 05:00:54 & 01:40:00 & First next picture, deposit fully inactive for some times. & $\mathrm{h}$ \\
\hline
\end{tabular}

\section{Discussion}

The sediment detention basin fillings described above took four major rainfall events on eighteen months in the Manival and only six minutes in the Claret. Nonetheless both processes showed similarities. The spreading of the sediment load in the artificially-widen basins drove first phase of both cases. The basin bottom slope was steeper in the Claret, the sediment transport capacity re-establishment thus only consisted in the confinement of the main flows between lateral deposits. The debris flow first spread and flowed on all of the 
basin width (Fig. 2a-c), but later mostly flowed in one obvious main channel confined by deposits (Fig. 2d-g).

On the contrary, the Manival basin had been dredged deeply with a mild bottom slope on the upper platform. The sediment continuity thus required the formation of a massive debris fan, steep enough and high enough to contain a confined channel with sufficient sediment transport capacity.

Once the sediment transport capacity was continuous until the open check dam, mechanical blockage occurred in both cases: coarse sediments or wood pieces jammed in the openings, obstructing them, and preventing the sediment to pass through the dam [4].
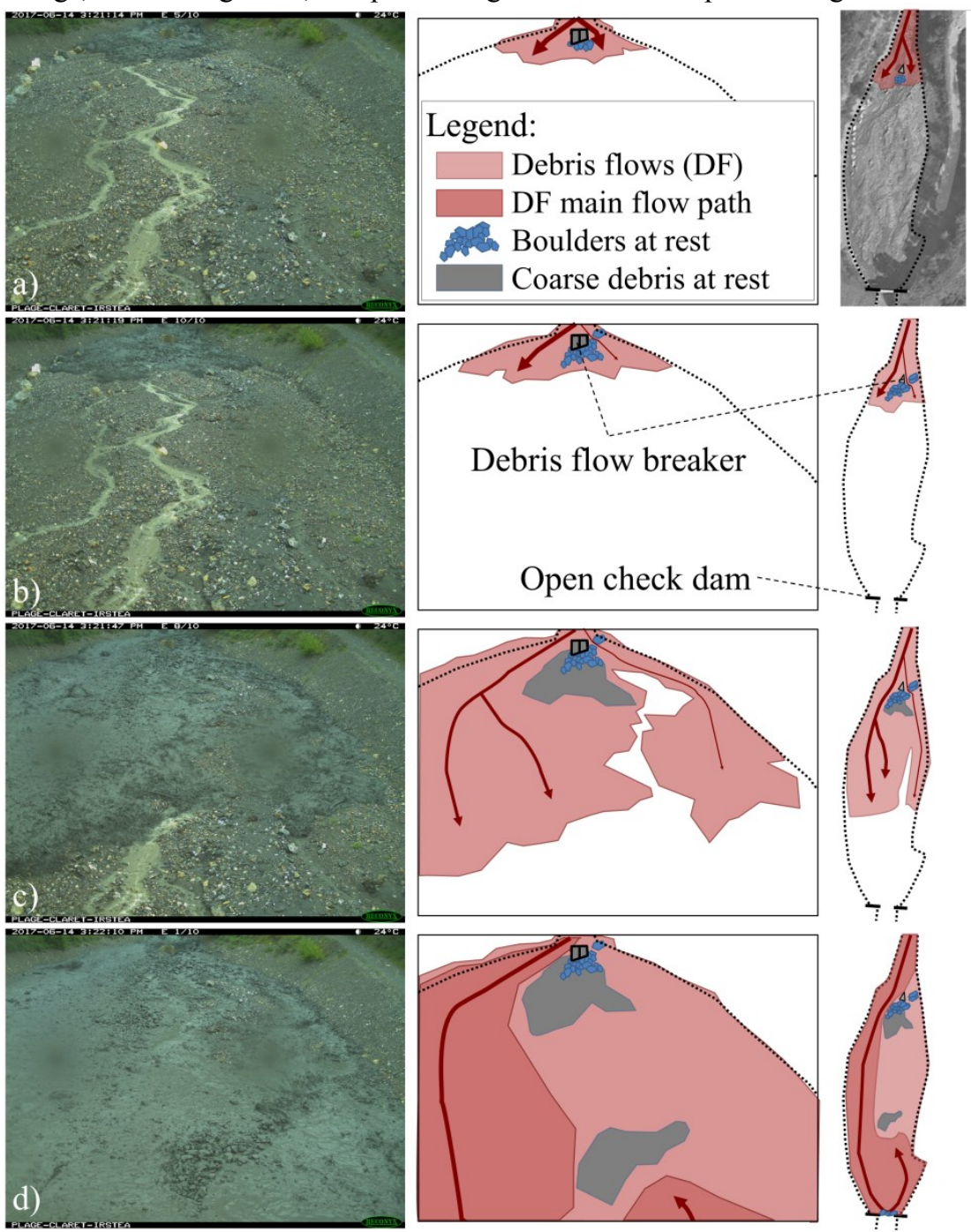

Fig. 2. Camera image, synthesis sketches (camera and aerial views) of several key steps in the debris flow deposition: (a) $\mathrm{T}=20 \mathrm{~s}$ after the debris flows reached the inlet, some boulders stopped behind the breaker; (b) $\mathrm{T}=25 \mathrm{~s}$, all the debris flow granular front was deposited; (c) $\mathrm{T}=53 \mathrm{~s}$, most of the flow was passing by the right flank of the deposit, rapidly spreading on all of the basin width; (d) $T=76 \mathrm{~s}$, most of the flow still come from the right, downstream a recirculating flow settled and appeared on the camera because the flows had reached the open check dam, clogging the bottom slot and filling the downstream basin part. This recirculation backfilled the basin until the deposit thickness reached the upper slot. 

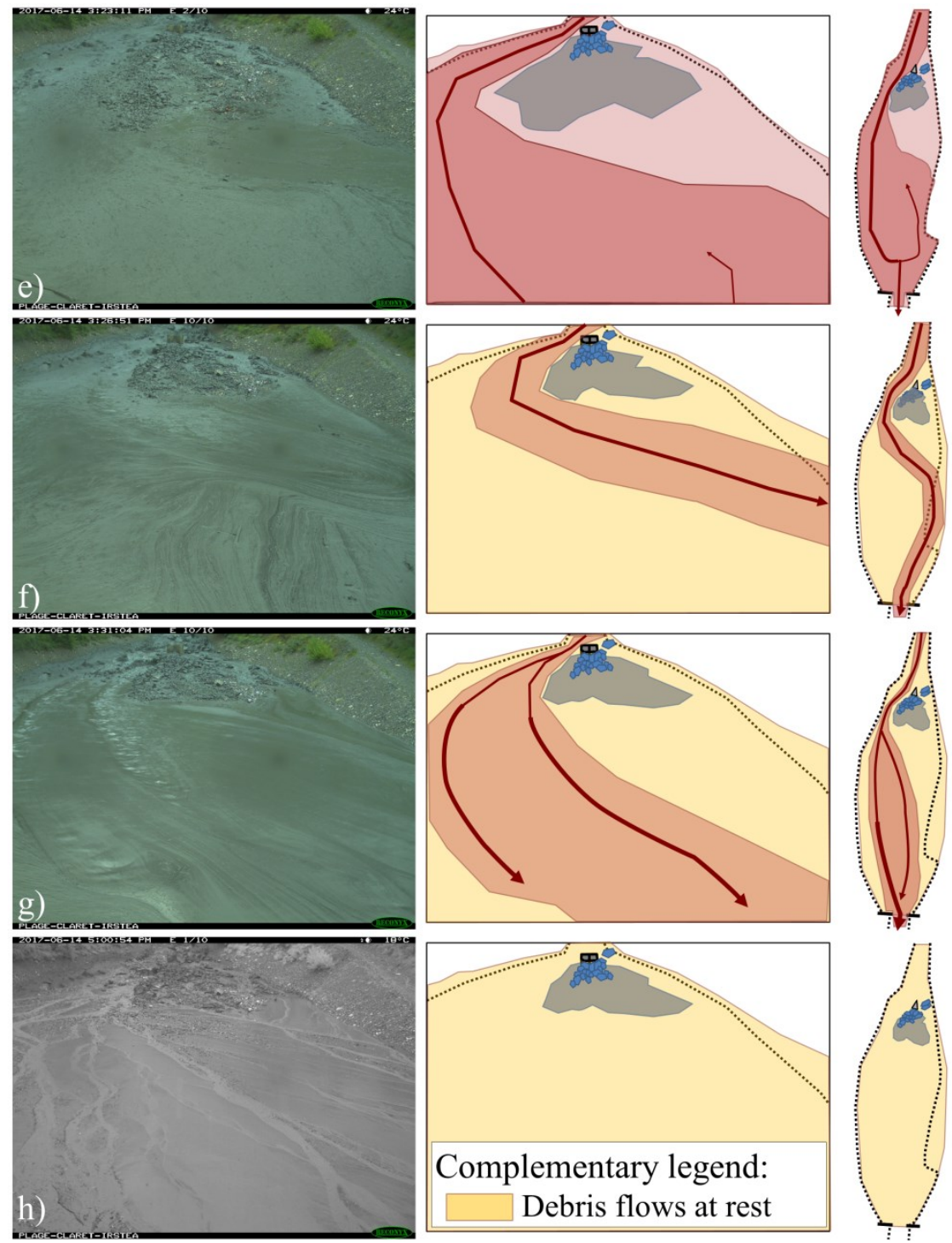

Fig. 2 (continued). (e) $\mathrm{T}=137 \mathrm{~s}$, the recirculating flow slowed down probably because most of the flow then passed by the upper slot; (f) $\mathrm{T}=297 \mathrm{~s}$, the basin filling was then maximum, most of the flow is concentrated on the deposit within an obvious path; $(\mathrm{g}) \mathrm{T}=610 \mathrm{~s}$, the self-cleaning was in progress, two obvious flow paths drain the remaining flow coming from upstream but overall the basin debris stage is decreasing. The lower transport activity at the inlet made the geophone activity passing under the threshold for image acquisition: camera stopped; (h) $\mathrm{T}=6,000 \mathrm{~s}$, a few pictures are taken of a deposit drained and inactive for some times.

From a broader perspective, the gravel deposition in the Manival sediment detention basin had some similarities with large scale alluvial fan formation. The fan shape was very regular and tended to occupy all the available room in the basin. Flows over the deposit occurred sometimes within one channel straight or meandering on the deposit (Fig. 1b), sometimes in multithread patterns (Fig. 1d) and more rarely in sheet-flow: a thin layer of water spreading on nearly all the fan (Fig. 1c). Avulsion cycles were clear and deserve to be analyzed more in details. Avulsion sometimes occurred (i) because of backwardpropagating deposition from a lobe at the fan toe, but also (ii) because of increasing water 
flow overtopping the channel banks, then feeding another fan channel that sometimes became the new main channel. The deposit geomorphic activity was very fast and strongly correlated to what happened at its downstream boundary, i.e., with or without sediment transport continuity from the platform to the channel.

All these processes have already been described in detail in the literature dedicated to alluvial fan formation and dynamics [10]. These new observations let us think that gravel deposition in sediment detention basins with mild slope and wide basins experiences strong self-similarity with fan formation although at a much lower scale. This existing literature can thus help managers of sediment detention basin to better understand their structures. Other observations of debris flows would be necessary to extend this assumption to debris fans. One must note that infiltration in gravel deposits likely play a key role in the system behavior, a role that possibly lose it importance at alluvial fan scales.

\section{Conclusion}

Despite fundamental differences of geomorphic activity, the debris flood or debris flow events tend to first fill sediment detention basins just enough to enable the sediment transport continuity reestablishment through the basin. The basin shape control the first phase of sediment deposition through it width (Claret and Manival) and its slope (Manival). In these two examples, the open check dams played a role only during the second phase of the filling, i.e., providing that the sediment transport continuity precondition was completed.

This result has strong implications on the basin dredging policy. If a manager seek to trap massive sediment pulses but would prefer small events to pass through the basin without deposit, a low flow channel with a suitable slope is necessary. These observations will help to enhance our comprehension of massive sediment trapping in torrents and to better adjust structure maintenance and design to the objective sought in each site.

This research was partially funded by the H2020 project NAIAD [grant no. 730497] from the European Union's Horizon 2020 research and innovation programme. The authors thanks the ONFRTM service for his support and partnership in the monitoring of the two sites.

\section{References}

[1] Chanson, H. J. of River Basin Management, 2, 301-307 (2004)

[2] Wang, H. W. \& Kondolf, G. J Am. Water. Resour. As., 50, 735-747 (2014)

[3] G. Piton, S. Carladous, A. Recking, F. Liebault, J. Tacnet, D. Kuss, Y. Quefféléan, \& O. Marco, Earth Surf. Process. Landforms 42, 91-108 (2016)

[4] G. Piton, \& A. Recking, J. Hydrau. Eng. 142(2):1-23. (2016)

[5] F. Fontaine, C. Bel, H. Bellot, G. Piton, F. Liebault, M. Juppet, \& K. Royer, Coll. EDYTEM, 19, 213-220 (2017)

[6] G. Piton, J. Berthet, C. Bel, F. Fontaine, H. Bellot, E. Malet, L. Astrade, A. Recking, F. Liebault, G. Astier, M. Juppet, \& K. Royer, Coll. EDYTEM, 19, 205-212 (2017)

[7] J. I. Theule, F. Liébault, A. Loye, D. Laigle, \& M. Jaboyedoff, Nat. Hazards Earth Syst. Sci., 12, 731-749 (2012)

[8] T. Hugerot, Etude des Trajectoires paysagères des dynamiques anthropoclimatiques des cônes de déjection torrentiels dans les Alpes du Nord l'exemple du cône déjection $d u$ Claret en Maurienne, (Univ. Savoie Mont Blanc, 2015)

[9] ONF-RTM73, Rapport d'évènement : Laves torrentielles du Claret et du Rieu Sec du 14 juin 2017 (Office National Des Forêts - Agence RTM Alpes Du Nord, 2017)

[10] A. Harvey, Earth Surf. Process. Landforms 37, 64-76 (2012) 